\title{
Evaluation of Three Candidate Genes Affecting Fatty Acid Composition in Pigs
}

\author{
Dyah Maharani ${ }^{1,2}$, Yeonkuk Jung ${ }^{1}$, Cheorun Jo ${ }^{1}$, Woo-Young Jung ${ }^{1}$, Ki-Chang Nam³ \\ Kang-Seok Seo ${ }^{3}$, Seung Hwan Lee ${ }^{4}$, and Jun-Heon Lee ${ }^{1 *}$ \\ ${ }^{I}$ Department of Animal Science and Biotechnology, Chungnam National University, Daejeon 305-764, Korea \\ ${ }^{2}$ Faculty of Animal Science, Gadjah Mada University, Yogyakarta 55281, Indonesia \\ ${ }^{3}$ Department of Animal Science and Technology, Sunchon National University, Sunchon 540-742, Korea \\ ${ }^{4}$ Hanwoo Experiment Station, National Institute of Animal Science, RDA, Pyeongchang 232-956, Korea
}

\begin{abstract}
The association of three candidate genes, fatty acid synthase (FASN), microsomal triglyceride transfer protein (MTTP) and fatty acid binding protein 3 (FABP3), with fatty acid (FA) composition in Duroc pigs was investigated. Identified single nucleotide polymorphisms (SNPs) were used for polymerase chain reaction-restriction fragment length polymorphism genotyping. The c.265C $>\mathrm{T}$ SNP of FASN gene was significantly associated with high levels of palmitoleic acid (C16:1) $(p<0.05)$, oleic acid (C18:1) $(p<0.01)$, and mono-unsaturated fatty acid (MUFA) $(p<0.01)$, but low levels of linoleic acid $(\mathrm{C} 18: 2)(p<0.01)$, alpha linolenic acid (C18:3) $(p<0.05)$, and poly-unsaturated fatty acid (PUFA) $(p<0.01)$ in animals having the CT genotype. The c.2573T>C SNP in the MTTP gene had a significant effect only in elevating the level of palmitoleic acid (C16:1) $(p<0.05)$ in heterozygote animals. The polymorphism in FABP3 showed no significant effects on any fatty acid composition traits. These results suggest that the identified SNPs in the FASN and MTTP genes can be useful markers for selecting Duroc pigs having desirable healthy fatty acid composition.
\end{abstract}

Key words: fatty acid synthase, microsomal triglyceride transfer protein, fatty acid binding protein 3, fatty acid composition, Duroc pig

\section{Introduction}

Fatty acid (FA) composition in meat is one of the main factors defining meat quality parameters including nutrition, sensory and functional aspects. The variation in FA composition, in particular saturated FAs (SFAs), affects the firmness of adipose tissue, which influences meat processing (Diana et al., 1998; Wood et al., 2008). Moreover, FAs are crucial in the control of cell metabolism, maintenance of an intact cell membrane, and improved nutrient use (Kim et al., 2006). The oxidative stability of muscle is also affected by FA composition, which in turn affects muscle flavor and color, which are the key factors of consumer acceptance. In humans, dietary FAs influence the risk of some diseases such as cardiovascular disease and diabetes (Lichtenstein, 2006). High intake of SFA can elevate plasma cholesterol, which contributes to

*Corresponding author: Jun-Heon Lee, Department of Animal Science and Biotechnology, Chungnam National University, Daejeon 305-764, Korea. Tel: 82-42-821-5779, Fax: 82-42825-9754, E-mail: junheon@cnu.ac.kr cardiovascular disease (Bronte et al., 1956). Moreover, SFAs such as lauric acid (C12:0), myristic acid (C14:0), and palmitic acid (C16:0) are considered to have the most harmful cardiovascular effects (Keys et al., 1974). However, high intake of polyunsaturated FA (PUFA) and monounsaturated FA (MUFA) increases hepatic low density lipoprotein (LDL) receptor activity, which leads to the decrease in the circulating concentration of LDL-cholesterol (Woollett et al., 1992). Therefore, producing and selecting animals having high quality meat with desirable FA composition is important for producers, researchers, and consumers.

Duroc breed has a high amount of marbling and has more a rapid growth rate than the Hampshire and the Yorkshire breed (Lowe et al., 2011; Wilson and Johnson, 1981). The high heritability (0.44) of lean growth rate in Duroc population indicated the lean growth rate can be improved by selecting animals having leanness and growth rate in the selection criteria (Chen et al., 2002). Moreover, fatty acid composition has also high heritability (for example, 0.54 for C18:0) in Duroc pig population, 
indicating selection can be efficiently applied (Suzuki et al., 2006).

The selection of animals having desired phenotypes including desired FA composition can be achieved using molecular approaches. Several genes affecting FA composition have been extensively investigated in some species. The FASN gene has been mapped on chromosome $17 \mathrm{q} 25$ in humans (Jayakumar et al., 1994). The porcine FASN gene is located on chromosome 12pl.5 and the location is consistent with the comparative mapping information between human and pig (Munoz et al., 2003). This gene plays an important role in catalyzing synthesis steps of palmitate from acetyle-CoA and malonyl-CoA (Roy et $a l ., 2005)$. The association of the FASN gene to FA composition has been investigated in cattle (Bhuiyan et al., 2009; Matsuhashi et al., 2010; Narukami et al., 2011; Zhang et al., 2008). Recently, the associations of FASN gene with $\mathrm{C} 16: 1$ and $\mathrm{C} 18: 1$ has been reported in Korean native pigs (KNP) $\times$ Yorkshire (YS) F2 population (Kim et al., 2011).

The MTTP gene, located on porcine chromosome 8, plays an essential role in lipid transfer during the assembly of lipoproteins in the liver and intestine (Hussain et al., 2003). This gene provides instructions for making a protein called MTTP that helps to produce apolipoprotein B (apoB) by the synthesis of triacylglycerol in the lumen of endoplasmic reticulum (ER) (Gordon et al., 1995). The MTTP protein may lead to further lipidation of nascent chylomicrons in apoB in rabbits (Cartwright et al., 2000) and in the ER of enterocytes in swine (Lu et al., 2002).

Heart fatty acid binding protein (H-FABP) or well known as FABP3 gene acts as a transporter from membrane to intracellular sites in FA metabolic pathways (Veerkamp and Maatman, 1995). In humans, this gene is located on chromosomes 1 and 13 (Veerkamp and Maatman, 1995), and is located on chromosome 6 in pigs (Gerbens et al., 1997). This gene is active in several tissues that have a high demand for FAs such as cardiac and skeletal muscles and lactating mammary glands (Gerbens et al., 1997).

In this study, the FASN, MTTP, and FABP3 genes were evaluated as candidates for monitoring the effects on FA composition in purebred Duroc pigs.

\section{Materials and methods}

\section{Animals and samples}

Muscle tissue samples from 71 purebred Duroc pigs (boar) were collected from four slaughter houses (Farm- sco, Emsung; Mokwoochon, Kimje; Daesung, Choonju; Kwangwon LPC, Wonju, Korea). The pigs were reared under the same feeding conditions including the fattening period from weaning weight $(30 \mathrm{~kg})$ to slaughter weight $(90 \mathrm{~kg})$. The longissimus thoracis samples were used for genomic DNA isolation and FA composition analysis.

\section{FA analysis}

Total lipid in each sample was extracted using chloroform-methanol $(2: 1, \mathrm{v} / \mathrm{v})$ according to the procedure of Folch et al. (1957). FA methyl esters were prepared from the extracted lipids with BF3-methanol (Sigma-Aldrich, USA) and separated on a HP-6890N gas chromatograph (Hewlett-Packard, USA). A split inlet (split ratio, 50:1) was used to inject samples into a $30 \mathrm{~m} \times 0.25 \mathrm{~mm} \times 0.25$ $\mu \mathrm{m}$ Omegawax 320 capillary column (Supelco, USA) and flame ionization detector was used. The oven temperature regimen consisted of $150^{\circ} \mathrm{C}$ for $3 \mathrm{~min}$, an increase to $180^{\circ} \mathrm{C}$ at $2.5^{\circ} \mathrm{C} / \mathrm{min}, 180^{\circ} \mathrm{C}$ for $5 \mathrm{~min}$, an increase to $220^{\circ} \mathrm{C}$ at $2.5^{\circ} \mathrm{C} / \mathrm{min}$, and $220^{\circ} \mathrm{C}$ for $25 \mathrm{~min}$. The injector and detector temperature were $210^{\circ} \mathrm{C}$ and $250^{\circ} \mathrm{C}$, respectively. $\mathrm{N}_{2}(99.999 \%)$ was the carrier gas at a constant flow of $0.7 \mathrm{~mL} / \mathrm{min}$. Relative quantities were expressed as weight percent of total fatty acids.

\section{DNA extraction and genotyping}

Genomic DNA samples were extracted from muscle samples and isolated by $20 \mathrm{mg} / \mathrm{mL}$ proteinase $\mathrm{K}$ digestion followed by phenol extraction. Primer sets and annealing temperature for polymerase chain reaction (PCR) amplification and sequencing of FASN, MTTP, and FABP3 genes and restriction enzyme information were as shown in Table 1. The PCR mixture contained $50 \mathrm{ng}$ genomic DNA, 10x buffer mix and $10 \mathrm{mM}$ dNTPs (GenetBio, Korea). Amplifications were performed at $10 \mathrm{~min}$ at $94^{\circ} \mathrm{C}, 35$ cycles of $30 \mathrm{sec}$ at $94^{\circ} \mathrm{C}, 30 \mathrm{sec}$ at the annealing temperature, and 30 sec at $72^{\circ} \mathrm{C}$, and a final extension of $10 \mathrm{~min}$ at $72^{\circ} \mathrm{C}$ using either a GeneAmp PCR system 2700 (Applied Biosystems, USA) or a $\mathrm{C} 1000^{\mathrm{TM}}$ Thermal Cycler (BioRad Laboratories, USA). The PCR products were visualized in $1.5 \%$ standard agarose gels stained with ethidium bromide (GenetBio, USA). Each PCR fragment was purified using an AccuPrep PCR Purification Kit (Bioneer, Korea). Purified PCR products were sequenced using the same primers for PCR reaction in a model $3730 \mathrm{XL}$ automated DNA Sequencer (Applied Biosystems). The DNA sequences were analyzed with the BioEdit program ver. 7.00 (Tom Hall, Ibis Therapeutics, USA) and the single nucleotide polymorphisms (SNPs) were confirmed based on the elec- 
Table 1. Primers for PCR amplification and restriction enzyme information for genotyping of FASN, MTTP and FABP3 genes

\begin{tabular}{|c|c|c|c|c|c|}
\hline Gene & $\begin{array}{c}\text { GenBank } \\
\text { accession No. }\end{array}$ & $\begin{array}{l}\text { Sequence } \\
\left(5^{\prime} \text { to } 3 \text { ') }\right.\end{array}$ & $\begin{array}{l}\text { Annealing } \\
\text { temp }\left({ }^{\circ} \mathrm{C}\right)\end{array}$ & $\begin{array}{c}\text { PCR product } \\
\text { size (bp) }\end{array}$ & $\begin{array}{c}\text { Restriction } \\
\text { enzyme }\end{array}$ \\
\hline FASN & AY183428 & $\begin{array}{l}\text { F: atcaacctgcttccettcgtg } \\
\text { R: cgcgctggcagcctatcat }\end{array}$ & 58 & 131 & Fnu4HI \\
\hline МТTP & $\begin{array}{l}\text { NM_214185 } \\
\text { (NC_010450) }\end{array}$ & $\begin{array}{l}\text { F: cagcgcggaaacagaagccg } \\
\text { R: acggtgcatcgtacccettcca }\end{array}$ & 65 & 1370 & $S m l \mathrm{I}$ \\
\hline FABP3 & X98558 & $\begin{array}{l}\text { F: cagcccaagagtgagtttcc } \\
\text { R: tgggctaggctgagaaagag }\end{array}$ & 58 & 451 & НруCH4V \\
\hline
\end{tabular}

trophoregram results. The SNPs in FASN, MTTP, and FABP3 genes were genotyped by the PCR-restriction fragment length polymorphism (PCR-RFLP) method. The restriction enzyme digestion was performed in $20 \mu \mathrm{L}$ reaction volumes with approximately $15 \mu \mathrm{L}$ of PCR products and 2 units of each restriction enzyme. The digested products were run on $3 \%$ agarose gels.

\section{Statistical analyses}

The effects of FASN, MTTP, and FABP3 genotypes on FA composition traits were tested using the ANOVA in the SPSS ver. 17.0 program (SPSS, USA). In order to test the pair wise differences between the effects of genotype, Tukey's test was also performed. Pearson's Chi-square test was used to test the allele and genotype frequency for Hardy-Weinberg equilibrium. The following model was used to test the association of the genotype and FAs composition:

$$
\mathrm{Y}_{\mathrm{i}}=\mu+\mathrm{G}_{\mathrm{i}}+\varepsilon_{\mathrm{i}}
$$

Where, $\mathrm{Y}$ is the phenotypic data (FA composition) of sample $i, \mu$ is the overall mean, $G$ is the genotype effect of sample $i$ and $\varepsilon$ is a random error.

\section{Results}

\section{FA composition profile}

Eleven FA composition traits were identified, including total SFA, MUFA, and PUFA. The number of FA composition traits detected in this study was higher than that reported by Estelle et al. $(2009 ; \mathrm{n}=10)$ and Lee et al. $(2010 ; n=8)$. Total SFA (C16:0 and C18:0) and MUFA (C16:1 and C18:1) were calculated by adding each of the two FAs. For total PUFA, four FAs that contained more than two double bonds were added. Total MUFA was higher than SFA and PUFA (Table 2).

Genotyping with PCR-RFLP and allele frequency Previously, the SNP at position 265 bp of porcine
Table 2. Fatty acid composition profile in Duroc pigs

\begin{tabular}{lrl}
\hline \hline \multicolumn{1}{c}{ Traits } & Mean & SD $^{1)}$ \\
\hline Palmitic acid (C16:0) & 25.73 & 1.10 \\
Palmitoleic acid (C16:1) & 2.95 & 0.47 \\
Stearic acid (C18:0) & 12.59 & 1.27 \\
Oleic acid (C18:1) & 41.78 & 4.60 \\
Linoleic acid (C18:2) & 13.92 & 3.06 \\
$\alpha$-Linolenic acid (C18:3) & 0.45 & 0.16 \\
Arachidonic acid (C20:4) & 2.67 & 1.26 \\
Docosahexaenoic acid (C22:6) & 0.54 & 1.45 \\
SFA $^{2)}$ & 38.32 & 1.97 \\
MUFA $^{3)}$ & 44.73 & 4.92 \\
PUFA $^{4)}$ & 16.95 & 4.47
\end{tabular}

${ }^{1)} \mathrm{SD}$, standard deviation of percentage fatty acid composition

${ }^{2)}$ SFA, saturated fatty acid

${ }^{3)}$ MUFA, monounsaturated fatty acid

${ }^{4)}$ PUFA, polyunsaturated fatty acid

FASN gene (Munoz et al., 2003) and the SNP located in exon 18 of MTTP gene (Estelle et al., 2009) was identified. In case of FABP3 gene, we identified four SNPs (g.1457G $>$ A, g. $1469 \mathrm{G}>A$, g. $1480 \mathrm{~T}>\mathrm{G}$ and g.1524T $>$ C) in 5'UTR region. Once the SNPs were identified, one SNP for each gene had been genotyped using PCR-RFLP. The 131 bp FASN gene PCR product was digested using Fnu4HI. Animals having the TT genotype have two fragments: 122 and $9 \mathrm{bp}$ (which is too small to appear on the gel under the conditions used). However, in this study, TT genotype animals could not identified, due to the low $\mathrm{T}$ allele frequency and relatively small sample size. The CC homozygous animals have three digested products: 67, 55, and $9 \mathrm{bp}$. Similarly, two restriction enzymes, SmlI and HpyCH4V, were used PCR-RFLP of MTTP and FABP3, respectively. The RFLP patterns were easily distinguishable for genotyping of each allele, as shown in Fig. 1. The genotype and allele frequencies were calculated and are presented in Table 3. Both FASN and MTTP genes displayed higher $\mathrm{C}$ allele frequencies than the $\mathrm{T}$ allele. Similarly, the CC genotype frequency was more than $50 \%$. However, the TT genotype was not detected in the FASN gene. In the case of FABP3, animals having the TT 
(a) FASN (c.265C >T)

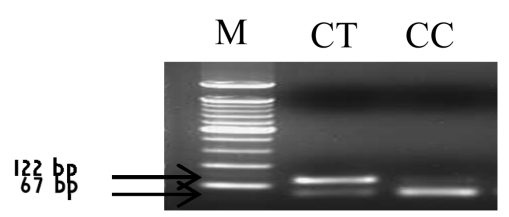

(b) FABP3 (g.1480T $>$ G)
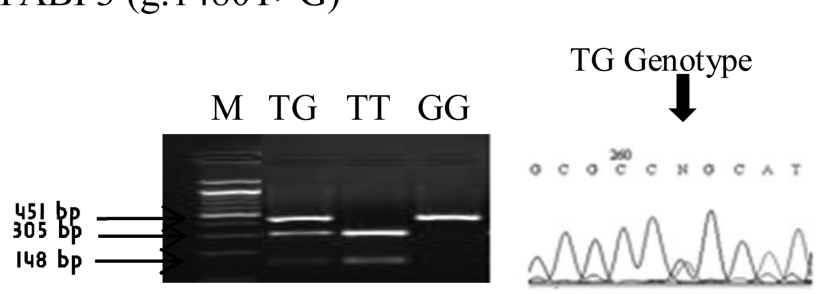

$(148,305,451 \mathrm{bp})$

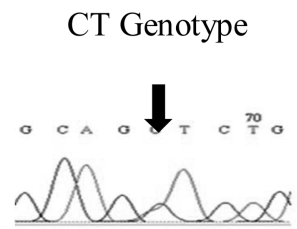

(122, $67 \mathrm{bp})$

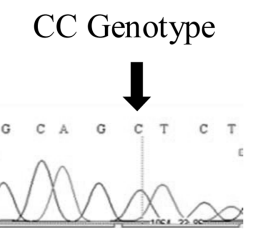

(67 bp)

(c) MTTP (c.2573T $>$ C or g.49297T $>$ C)

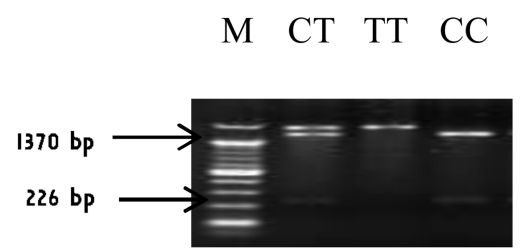

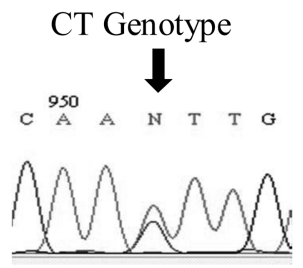

$(1370,1144,226$ bp)

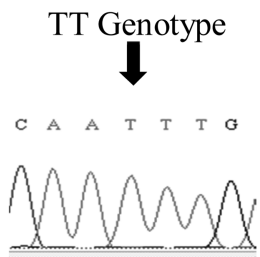

(1370 bp)

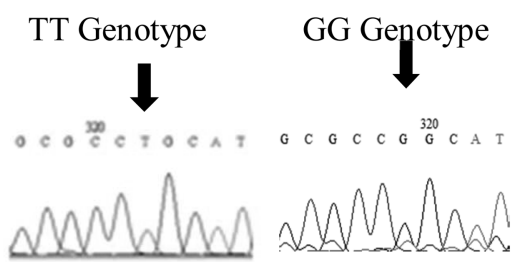

(451 bp)

Fig. 1. PCR-RFLP genotyping results for the FASN (a), FABP3 (b), and MTTP (c) genes.

Table 3. Allele and genotype frequencies for FASN, MTTP, and FABP3 genes in Duroc pigs

\begin{tabular}{|c|c|c|c|c|c|c|c|}
\hline Gene & SNP & \multicolumn{2}{|c|}{ Allele frequency } & \multicolumn{3}{|c|}{ "Genotype frequency } & 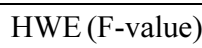 \\
\hline \multirow{2}{*}{ FASN } & \multirow[t]{2}{*}{ c. $265 \mathrm{C}>\mathrm{T}$} & $\mathrm{C}$ & $\mathrm{T}$ & $\mathrm{CC}$ & $\mathrm{CT}$ & TT & \multirow[t]{2}{*}{0.0046} \\
\hline & & 0.97 & 0.03 & 0.94 & 0.06 & 0 & \\
\hline \multirow{2}{*}{ МТTP } & c. $2573 \mathrm{~T}>\mathrm{C}$ & $\mathrm{C}$ & $\mathrm{T}$ & $\mathrm{CC}$ & $\mathrm{CT}$ & TT & \multirow{2}{*}{34.43} \\
\hline & (g.49297T $>C$ ) & 0.83 & 0.17 & 0.79 & 0.08 & 0.13 & \\
\hline \multirow{2}{*}{ FABP3 } & \multirow{2}{*}{ g. $1480 \mathrm{~T}>\mathrm{G}$} & $\mathrm{T}$ & G & TT & TG & GG & \multirow{2}{*}{1.75} \\
\hline & & 0.79 & 0.21 & 0.65 & 0.28 & 0.07 & \\
\hline
\end{tabular}

HWE, Hardy-Weinberg equilibrium

genotype had the highest frequency compared with TG and GG animals. Pearson's Chi-square test was used to test the Hardy-Weinberg equilibrium. The genotypes of the FASN and FABP3 genes were in Hardy-Weinberg equilibrium. However, the genotype of the MTTP gene deviated from the Hardy-Weinberg equilibrium.

\section{Effects of SNP genotypes with FA composition}

The SNP at position 265 bp of porcine FASN gene was significantly affect in high C16:1 $(p<0.05), \mathrm{C} 18: 1(p<0.01)$, and MUFA $(p<0.01)$ for the heterozygous (CT) animals. The CC genotypes also displayed significantly increased C18:2 $(p<0.01), \mathrm{C} 18: 3(p<0.05)$, and PUFA $(p<0.01)$ than the animals having the CT genotype. For the MTTP gene, only $\mathrm{C} 16: 1(p<0.05)$ was significantly associated in the animals having CT genotypes. On the other hand, animals with the $\mathrm{CC}$ genotype were suggestively linked with high SFA $(p=0.071)$. In the case of FABP3 gene, no significant association was observed with the FA composition traits.

\section{Discussion}

The FA composition profile was shown in Table 2 . Interestingly, this result detected the rare FA docosahexaenoic acid (DHA). DHA is essential for infants, 
Table 4. The effect of SNPs in FASN, MTTP, and FABP3 genes with fatty acid composition in Duroc pigs

\begin{tabular}{|c|c|c|c|c|c|c|c|c|}
\hline \multirow{3}{*}{ Fatty acid } & \multirow{2}{*}{\multicolumn{2}{|c|}{$\begin{array}{l}\text { FASN } \\
.265 \mathrm{C}>\mathrm{T}\end{array}$}} & \multicolumn{3}{|c|}{ "MTTP } & \multicolumn{3}{|c|}{ "FABP3 } \\
\hline & & & \multicolumn{3}{|c|}{ c.2573T $>C($ g.49297T $>C)$} & \multicolumn{3}{|c|}{ g.1480T $>\mathrm{G}$} \\
\hline & $\mathrm{CC}$ & CT & $\mathrm{CC}$ & CT & TT & TT & TG & GG \\
\hline Palmitic acid (C & $25.75 \pm 0.14$ & $25.33 \pm 0$ & $5.85 \pm 0.14$ & $25.56 \pm 0.44$ & $25.05 \pm 0$ & $25.81 \pm 0.16$ & $25.69 \pm 0.25$ & $25.13 \pm 0.49$ \\
\hline Palmitoleic acid (C16:1) & $2.92 \pm 0.05^{\mathrm{a}}$ & $3.49 \pm 0.23^{\mathrm{b}}$ & $2.88 \pm 0.06^{\mathrm{a}}$ & $3.22 \pm 0.19^{\mathrm{a}}$ & $3.21 \pm 0.15^{\mathrm{b}}$ & $2.93 \pm 0.07$ & $2.99 \pm 0.11$ & 2.98 \\
\hline Stearic acid (C18:0) & $12.65 \pm 0.15$ & $11.63 \pm 0.63$ & $12.73 \pm 0.17$ & $12.24 \pm 0.51$ & $11.99 \pm 0.42$ & $12.55 \pm 0.19$ & $12.77 \pm 0.29$ & $12.30 \pm 0.57$ \\
\hline Oleic acid (C18:1) & $41.39 \pm 0.53^{\mathrm{a}}$ & $48.21 \pm 2.18^{\mathrm{b}}$ & $41.32 \pm 0.61$ & $44.04 \pm 1.87$ & $43.14 \pm 1.53$ & $41.73 \pm 0.68$ & $41.36 \pm 1.03$ & $43.92 \pm 2.07$ \\
\hline Linoleic acid (C18:2) & $13.54 \pm 0.36^{\mathrm{a}}$ & $9.17 \pm 1.45^{\mathrm{b}}$ & $13.53 \pm 0.41$ & $11.83 \pm 1.25$ & $12.81 \pm 1.02$ & $13.54 \pm 0.45$ & $13.14 \pm 0.68$ & $11.66 \pm 1.37$ \\
\hline$\alpha$-Linolenic acid (C18 & $0.46 \pm 0.02^{\mathrm{a}}$ & $0.26 \pm 0.08^{b}$ & $0.47 \pm 0.02$ & $0.44 \pm 0.06$ & $0.36 \pm 0.05$ & $0.46 \pm 0.02$ & $0.45 \pm 0.04$ & $0.36 \pm 0.07$ \\
\hline Arachidonic acid (C20:4) & $2.73 \pm 0.15$ & $1.76 \pm 0.63$ & $2.65 \pm 0.17$ & $2.49 \pm 0.52$ & $2.91 \pm 0.43$ & $2.60 \pm 0.19$ & $2.85 \pm 0.29$ & $2.59 \pm 0.57$ \\
\hline Docosahexaenoic acid (C22:6) & $0.56 \pm 0.18$ & $0.16 \pm 0.73$ & $0.57 \pm 0.20$ & $0.18 \pm 0.60$ & $0.54 \pm 0.49$ & $0.39 \pm 0.22$ & $0.74 \pm 0.33$ & $1.07 \pm 0.65$ \\
\hline $\mathrm{SFA}^{1)}$ & $38.40 \pm 0.24$ & $36.95 \pm 0.98$ & $38.58 \pm 0.26$ & $37.80 \pm 0.79$ & $37.03 \pm 0.64$ & $38.35 \pm 0.29$ & $38.46 \pm 0.44$ & $37.43 \pm 0.89$ \\
\hline MUFA $^{2)}$ & $44.31 \pm 0.57^{\mathrm{a}}$ & $51.70 \pm 2.32^{\mathrm{b}}$ & $44.19 \pm 0.65$ & $47.26 \pm 1.99$ & $46.35 \pm 1.63$ & $44.65 \pm 0.73$ & $44.35 \pm 1.11$ & $49.90 \pm 2.23$ \\
\hline PUFA $^{3)}$ & $17.29 \pm 0.52^{\mathrm{a}}$ & $11.35 \pm 2.14^{\mathrm{b}}$ & $17.22 \pm 0.60$ & $14.94 \pm 1.83$ & $16.61 \pm 1.50$ & $17.00 \pm 0.67$ & $17.19 \pm 1.01$ & $15.68 \pm 2.02$ \\
\hline
\end{tabular}

${ }^{1)}$ SFA, saturated fatty acid

${ }^{2)}$ MUFA, monounsaturated fatty acid

${ }^{3)}$ PUFA, polyunsaturated fatty acid

especially for growth and functional development of the brain (Horrocks and Lee, 1999). Plentiful dietary DHA improves learning ability of infants. This result also indicates that Duroc pigs have a greater proportion of UFA than other animals, which is important concerning dietary alterations in pigs, poultry and fish (Bou et al., 2009; Jung et al., 2010; Kim et al., 2007). Myristic acid (C14:0) was not detectable in the current Duroc pig population. In contrast, previous studies detected myristic acid in Iberian, Duroc and Berkshire pigs (Estelle et al., 2009; Gallardo et al., 2009; Lee et al., 2010). The breed differences might influence the variation of FAs. Zhang et al. (2009) reported that breed and sex are important sources of variation for FA composition of porcine longissimus muscle; in the study, Duroc pigs had greater total SFA and lower total MUFA compared to nine other pig breeds. In contrast, using the same breed (Duroc pig), total MUFA was higher than total SFA in the current study. Another study reported that sex differences affect to FA composition in pig Pitman-moor miniature (Filer et al., 1974). Manipulation of the diet also can greatly influence the variation of FA composition. In one study, the incorporation of whole linseed (Linum usitatissimum) in the diet of finishing Great Britain pigs affected the concentration of docosapentaenoic acid (DPA) in muscle, liver, and kidney, and DHA in plasma (Matthews et al., 2000). The collective results support the view that FA profile in pigs can vary under the influences of selected population, breed, diet, and gender.

The pig FASN gene is located on chromosome 12p1.5 (Munoz et al., 2003). The latter study identified two synonymous SNPs at position 196 and 265; both represented a $\mathrm{C}>\mathrm{T}$ transition. Moreover, the authors suggested the position obtained for the FASN gene in SSC12 is close to a qualitative trait locus (QTL) detected an effect on backfat FA composition. The current study confirmed that one of those SNPs at position 265 had a significant effect on all UFAs. In heterozygote animals, significant associations of the SNPs with elevated levels of C16:1, C18:1 and MUFA were apparent. On the other hand, significant affects were also detected concerning the elevated levels of C18:2, C18:3, and PUFA in homozygote animals. Similarly, using the same SNP, Kim et al. (2011) reported the gene had same effects in high level of C16:1 and C18:1 in Korean native pig (KNP) $\times$ Yorkshire (YS) F2 population. Our study might thus prove to be useful for the selection of animals having desirably-elevated levels of UFAs in the pig breeding industry. These results are also important because the high intake of MUFA and PUFA seem to increase hepatic low density lipoprotein (LDL) receptor activity, which can decrease the amount of circulating LDL-cholesterol, which is, in turn, detrimental for cardiovascular health (Woollett et al., 1992).

The MTTP gene has been analyzed as a positional candidate gene for a QTL located in chromosome 8 (Estelle et al., 2005). The same previously detected QTL region was demonstrated to affect FA composition in Iberian pigs by a Landrace $\mathrm{F}_{2}$ cross (Clop et al., 2003). In this study, we evaluated the influence of the porcine MTTP gene on FA composition in Duroc pigs. The c.2573T $>\mathrm{C}$ (g.49297T >C) SNP of the MTTP gene similarly elevated the content of C16:1 in heterozygote animals. The present results echo those of Estelle et al. (2009), who reported that the SNP markedly influenced the contents of palmitic acid (C16:0), and vaccenic acid (C18:1 $\mathrm{n}=7)$ in $\mathrm{C}$ 
allele. The SNP also increased lipid transfer activity in homozygous $\mathrm{CC}$ animals than in other genotypes. A previous study reported the up-regulation and altered composition of FAs, and the down-regulated MTTP expression in developing swine (Lu et al., 2002). The study provided evidence that the degree of MTTP expression appeared to regulate the type of FA and was proportional to triacylglycerol secretion efficiency and also by a high-fat introduodenal infusion of lipid containing 18-carbon UFAs in mRNA of MTTP expression of piglet jejunum. These results may be germane not only for pork quality but also for human health, because human MTTP genotypes have been associated with a considerable number of metabolic disorders such as coronary heart disease and diabetes levels in a Mexican population (Luevano et al., 2009) and Hepatitis B infection in a Chinese population (Yang et al., 2008).

Using the porcine sequence-specific DNA from a pig/ rodent cell hybrid line, the FABP3 gene was localized on chromosome 6 (Gerbens et al., 1997). The authors revealed the gene's variation in seven pig breeds using three different restriction enzymes; three polymorphisms were present in all breed for HinfI RFLP but not for HaeIII and $M s p$ I in the Hampshire and Meishan breeds. In Duroc pigs, the HinfI allele frequency distribution was at disequilibrium. The results were confirmed by Lee et al. (2010) concerning the detection of the association of the gene with FA composition in the Berkshire breed. In contrast, the same study reported that the MspI RFLP genotype of FABP 3 affected the UFA content and the ratio of PUFA to SFA in the Berkshire breed, whereas no effect was discerned using Hinfl and HaeIII RFLPs (Lee et al., 2010). In case of our study, four SNPs were detected in the same region (exon 1) reported by Lee et al. (2010). Of these, the g.1480T $>$ G SNP of FABP3 gene was selected for genotyping using the $H p y \mathrm{CH} 4 \mathrm{~V}$ restriction enzyme. No association between the SNP and FA composition was evident. Breed differences might explain the varying influence of genes on FA composition.

The polymorphisms in two candidate genes (FASN and MTTP) influenced FA composition in the longissimus thoracis muscle of Duroc pigs. The SNPs in these two genes may be useful for developing molecular markers for the selection of Duroc pigs having desirable FA composition.

\section{Acknowledgement}

This research was supported by a grant from the NextGeneration BioGreen 21 Program (No. PJ0081162011), Rural Development Administration, Republic of Korea and Technology Development Program (Project no. 11006103-1-CG000) for Agriculture and Forestry, Ministry for Food, Agriculture, Forestry and Fisheries, Republic of Korea.

\section{References}

1. Bhuiyan, M. S. A., Yu, S. L., Jeon, J. T., Yoon, D., Cho, Y. M., Park, E. W., Kim, E. W., Kim, K. S., and Lee, J. H. (2009) DNA polymorphisms in SREBF1 and FASN genes affect fatty acid composition in Korean cattle (Hanwoo). Asian-Aust. J. Anim. Sci. 22, 765-773.

2. Bou, R., Codony, R., Tres, A., Decker, E. A., and Guardiola, F. (2009) Dietary strategies to improve nutritional value, oxidative stability, and sensory properties of poultry products. Crit. Rev. Food Sci. Nutr. 49, 800-822.

3. Bronte, S. B., Antonis, A., Eales, L., and Brock, J. F. (1956) Effects of feeding different fats on serum-cholesterol level. Lancet 270, 521-526.

4. Cartwright, I. J., Plonne, D., and Higgins, J. A. (2000) Intracellular events in the assembly of chylomicrons in rabbit enterocytes. J. Lipid. Res. 41, 1728-1739.

5. Chen, P., Baas, T. J., Mabry, J. W., Dekkers, J. C., and Koehler, K. J. (2002) Genetic parameters and trends for lean growth rate and its comvonents in U.S. Yorkshire, Duroc, Hampshire, and Landrace pigs. J. Anim. Sci. 80, 2062-2070.

6. Clop, A., Ovilo, C., Perez-Enciso, M., Cercos, A., Tomas, A., Fernandez, A., Coll, A., Folch, J. M., Barragan, C., Diaz, I., Oliver, M. A., Varona, L., Silio, L., Sanchez, A., and Noguera, J. L. (2003) Detection of QTL affecting fatty acid composition in the pig. Mamm. Genome 14, 650-656.

7. Diana, P., Nichols, P. J., and Thompson, J. M. (1998) The effect of sire breed on the melting point and fatty acid composition of subcutaneous fat in steers. J. Anim. Sci. 76, 87-95.

8. Estelle, J., Sanchez, A., and Folch, J. M. (2005) Assignment of the microsomal triglyceride transfer protein large subunit (MTP) gene to porcine chromosome 8. Anim. Genet. 36, 354-355.

9. Estelle, J., Fernandez, A. I., Perez-Enciso, M., Fernandez, A., Rodriguez, C., Sanchez, A., Noguera, J. L., and Folch, J. M. (2009) A non-synonymous mutation in a conserved site of the MTTP gene is strongly associated with protein activity and fatty acid profile in pigs. Anim. Genet. 40, 813-820.

10. Filer, L. J., Fomon, S. J., Anderson, T. A., Nixt, T. L., and Andersen, D. W. (1974) Effects of age, sex, and diet upon carcass and liver fatty acid composition of Pitman-Moore miniature pigs. Lipids 9, 536-540.

11. Folch, J., Lees, M. and Stanley, G. H. S. (1957) A simple method for the isolation and purification of total lipides from animal tissues. J. Biol. Chem. 226, 497-509.

12. Gallardo, D., Quintanilla, R., Varona, L., Diaz, I., Ramirez, O., Pena, R. N., and Amills, M. (2009) Polymorphism of the pig acetyl-coenzyme A carboxylase alpha gene is associated with fatty acid composition in a Duroc commercial line. Anim. Genet. 40, 410-417.

13. Gerbens, F., Rettenberger, G., Lenstra, J. A., Veerkamp, J. H., 
and te Pas, M. F. (1997) Characterization, chromosomal localization, and genetic variation of the porcine heart fatty acid-binding protein gene. Mamm. Genome 8, 328-332.

14. Gordon, D. A., Wetterau, J. R., and Gregg, R. E. (1995) Microsomal triglyceride transfer protein: a protein complex required for the assembly of lipoprotein particles. Trends Cell. Biol. 5, 317-321.

15. Horrocks, L. A. and Yeo, Y. K. (1999) Health benefits of docosahexaenoic acid (DHA). Pharmacol. Res. 40, 211-225.

16. Hussain M. M., Shi, J., and Dreizen, P. (2003) Microsomal triglyceride transfer protein and its role in apoB-lipoprotein assembly. J. Lipid Res. 44, 22-32.

17. Jayakumar, A., Chirala, S. S., Chinault, A. C., Baldini, A., Abu-Elheiga, L., and Wakil, S. J. (1994) Isolation and chromosomal mapping of genomic clones encoding the human fatty acid synthase gene. Genomics 23, 420-424.

18. Jung S., Choe, J. H., Kim, B., Yun, H., Kruk, Z. A., and Jo, C. (2010) The effect of dietary mixture of gallic acid and linoleic acid on antioxidative potential and quality of breast meat from broilers. Meat Sci. 86, 520-526.

19. Keys, A., Grande, F., and Anderson, J. T. (1974) Bias and Misrepresentation revisited: perspective in saturated fat. $\mathrm{Am}$. J. Clin. Nutr. 27, 188-212.

20. Kim, Y., Kong, M., Nam, Y. J., and Lee, C. (2006) A quantitative trait locus for oleic fatty acid content on Sus scrofa chromosome 7. J. Hered. 97, 535-537.

21. Kim, J. H., Hwangbo, J., Choi, N. J., Park, H. G., Yoon, D. H., Park, W., Lee, S. H., Park, B. K., and Kim, Y. F. (2007) Effect of dietary supplementation with conjugated linoleic acid, with oleic, linoleic, or linolenic acid, on egg quality characteristics and fat accumulation in the egg yolk. Poultry Sci. 86, 1180-1186.

22. Kim, S. W., Choi, Y. I., Choi, J. S., Kim, J. J., Choi, B. H., Kim, T. H., and Kim, K. W. (2011) Porcine fatty acid synthase gene polymorphisms are associated with meat quality and fatty acid composition. Korean J. Food Sci. An. 31, 356-365.

23. Lee, S. H., Choi, Y. M., Choe, J. H., Kim, J. M., Hong, K. C., Park, H. C., and Kim, B. C. (2010) Association between polymorphisms of the heart fatty acid binding protein gene and intramuscular fat content, fatty acid composition, and meat quality in Berkshire breed. Meat Sci. 86, 794-800.

24. Lichtenstein, A. H. (2006) Thematic review series: patientoriented research. Dietary fat, carbohydrate, and protein: effects on plasma lipoprotein patterns. J. Lipid Res. 47, 1661-1667.

25. Lowe, B. K., Clark, D. L., Boler, D. D., Dilger, A. C., McKeith, F. K., Eggert, J. M., Newcom, D. W., and Killefer, J. (2011) Characterization of loin shape from Duroc and Duroc composite finishing gilts. Meat Sci. 87, 146-150.

26. Lu, S., Huffman, M., Yao, Y., Mansbach, C. M., Cheng, X., Meng, S., and Black, D. D. (2002) Regulation of MTP expression in developing swine. J. Lipid Res. 43, 1303-1311.

27. Luevano, K. E., Gonzalez, J. R., Perea, F. J., and Magana, M. T. (2009) Linkage disequilibrium between four MTTP gene polymorphisms in a Mexican population. Ann. Hum. Biol. 36, 211-219.

28. Matsuhashi, T., Maruyama, S., Uemoto, Y., Kobayashi, N.,
Mannen, H., Abe, T., Sakaguchi, S., and Kobayashi, E. (2010) Effects of FASN, SCD, SREBP1 and GH gene polymorphisms on fatty acid composition and carcass traits in Japanese Black cattle. J. Anim. Sci. 89, 12-22.

29. Matthews, K. R., Homer, D. B., Thies, F., and Calder, P. C. (2000) Effect of whole linseed (Linum usitatissimum) in the diet of finishing pigs on growth performance and on the quality and fatty acid composition of various tissues. Br. $J$. Nutr. 83, 637-643.

30. Munoz, G., Ovilo, C., Noguera, J. L., Sanchez, A., Rodriguez, C., and Silio, L. (2003) Assignment of the fatty acid synthase (FASN) gene to pig chromosome 12 by physical and linkage mapping. Anim. Genet. 34, 234-235.

31. Narukami, T., Sasazaki, S., Oyama, K., Nogi, T., Taniguchi, M., and Mannen, H. (2011) Effect of DNA polymorphisms related to fatty acid composition in adipose tissue of Holstein cattle. Anim. Sci. J. 82, 406-411.

32. Roy, R., Zaragoza, P., Gautier, M., Eggen, A., and Rodellar, C. (2005) Radiation hybrid and genetic linkage mapping of two genes related to fat metabolism in cattle: fatty acid synthase (FASN) and glycerol-3-phosphate acyltransferase mitochondrial (GPAM). Anim. Biotechnol. 16, 1-9.

33. Suzuki K., Ishida M., Kadowaki H., Shibata T., Uchida H., and Nishida A. (2006) Genetic correlations among fatty acid compositions in different sites of fat tissues, meat production, and meat quality traits in Duroc pigs. J. Anim. Sci. 84, 20262034.

34. Veerkamp, J. H. and Maatman, R. G. (1995) Cytoplasmic fatty acid-binding proteins: their structure and genes. Prog. Lipid Res. 34, 17-52.

35. Wilson, E. R. and Johnson, R. K. (1981) Comparison of three-breed and backcross swine for litter productivity and post weaning performance. J. Anim. Sci. 52, 18-25.

36. Wood, J. D., Enser, M., Fisher, A. V., Nute, G. R., Sheard, P. R., Richardson, R. I., Hughes, S. I., and Whittington, F. M. (2008) Fat deposition, fatty acid composition and meat quality: A review. Meat Sci. 78, 343-358.

37. Woollett, L. A., Spady, D. K., and Dietchy, J. M. (1992) Saturated and unsaturated fatty acid independently regulate low density lipoprotein receptor activity and production rate. $J$. Lipid Res. 33, 77-88.

38. Yang, Z. T., Zhang, X. X., Kong, X. F., Zhang, D. H., Zhang, S. Y., Jiang, J. H., Gong, Q. M., Jin, G. D., and Lu, Z. M. (2008) Polymorphisms of microsomal triglyceride transfer protein in different hepatitis B virus-infected patients. World J. Gastroenterol. 14, 5454-5460.

39. Zhang, S., Knight, T. J., Reecy, J. M., and Beitz, D. C. (2008) DNA polymorphisms in bovine fatty acid synthase are associated with beef fatty acid composition. Anim. Genet. 39, 62-70.

40. Zhang, S., Knight, T. J., Stalder, K. J., Goodwin, R. N., Lonergan, S. M., and Beitz, D. C. (2009) Effects of breed, sex and halothane genotype on fatty acid composition of triacylglycerols and phospholipids in pork longissimus muscle. J. Anim. Breed Genet. 126, 259-268.

$\overline{\text { (Received 2011.8.29/Revised 2011.12.6/Accepted 2011.12.7) }}$ 